\title{
The Influence of School Principal's Leadership Styles and School Culture on the Teachers Performance
}

\author{
Bakhtiar Yusup ${ }^{1}$, Yahya Sudarya ${ }^{2}$, Widyanti $^{3}$, Sulastri $^{4}$ \\ \{ bakhtiaryusup12@gmail.com ${ }^{1}$, yahyasudarya@yahoo.com², widyanti02@gmail.com ${ }^{3}$, \\ lastrie72@gmail.com $\left.{ }^{4}\right\}$ \\ ${ }^{1}$ SMP Muhammadiyah 1 Purwokerto \\ ${ }^{2}$ Magister Pendidikan Dasar, Universitas Muhammadiyah Purwokerto \\ ${ }^{3}$ SDN Kutawaru 01 Cilacap \\ ${ }^{4}$ SD Negeri 2 Beji Kedungbanteng, Banyumas
}

\begin{abstract}
School management success is influenced by factors such as the principal's leadership style and the school culture. The goal of this research was to see how the principal's leadership style and school culture affected the performance of Muhammadiyah Junior High School teachers. To explain the associative relationship between the independent variable and the dependent variable, this study employs survey research with a correlational quantitative approach. This study included 67 Muhammadiyah junior high school teachers from Purwokerto, Banyumas Regency. A questionnaire was used to collect data. The normality, linearity, and multicollinearity tests were used to assess data validity. Multiple regression tests are used to test the hypothesis. According to the findings, the principal's leadership style and school culture had a significant impact on the performance of Muhammadiyah junior high school teachers in Purwokerto, Banyumas Regency.
\end{abstract}

Keywords: leadership style, school culture, teacher performance, junior high school

\section{Introduction}

Many factors affect the quality of education, one of which is the role of the teacher. In his position the teacher has a strategic role in the advancement of education, not only as a teacher and educator, currently the teacher has a more complex role. According to Law Number 14 of 2005 concerning Teachers and Lecturers, in addition to educating and teaching, teachers also play a role in guiding, directing, training, assessing, and evaluating students. In addition, in learning activities in the classroom, the role of the teacher has also changed. At first the teacher was dominant in the classroom, as the only source of learning, now in learning in the classroom the teacher is required to act more as a motivator and facilitator.

The role of the teacher in the success of learning activities is undeniable. Teacher performance has an impact on the quality of learning in the classroom. Good teacher performance will create good learning activities so that they can improve the quality of education in their schools. Currently, there are still Muhammadiyah junior high school teachers in Purwokerto who have poor performance. This is based on initial observations that there are still teachers whose performance is classified as low, for example: being late, coming home early, arranging learning tools that are not in accordance with the provisions, teaching without clear methods and completing assignments not on time. In addition, the quality of education, especially in the academic field, Muhammadiyah Junior High School in Purwokerto, Banyumas Regency is still lagging behind state schools.Based on these problems, it is necessary to make 
efforts to improve the quality of education in SMP Muhammadiyah in Purwokerto, Banyumas district. One of the efforts to improve the quality of education is to improve teacher performance.

Teacher performance has an impact on the quality of learning in the classroom. Good teacher performance will create good learning activities so that they can improve the quality of education in their schools. Factors that affect teacher performance include the principal's leadership style and school culture. According to Supardi in Ardiana, factors that influence teacher performance include the environment, management behavior, job design, performance appraisal, feedback and remuneration administration [1]. Meanwhile, according to Timpe in Gusman, the factors that influence teacher performance are [2]: (1) work environment, (2) work motivation, (3) leadership style, (4) behavior, (5) attitude, and (6) relationship with coworkers.

The principal's leadership style can determine the intensity and quality of teacher performance in carrying out their duties, because after all a superior in an organization plays an important role in determining the direction of work of his subordinates [3]. There are several types of principal leadership styles. According to Baihaqi, the types of leadership styles are [4]: 1) Autocratic / Authoritarian type, namely government or power held by someone who is in full power and is not limited in time. While those who hold power are called autocrats, which are usually held by leaders who have the status of kings or who use the royal system. 2) LaissezFaire type, namely the principal as a laissez-faire type leader wants all components of education actors to carry out their duties freely. 3) Democratic Type Democratic leadership is leadership based on democracy whose implementation is called participatory leadership. Participatory leadership is a way of leader whose strength lies in the active participation of every member of the group.

School culture affects performance. According to Deal and Peterson in Supardi, school culture is a set of values that underlie behavior, traditions, daily habits, and symbols that are practiced by principals, teachers, administrative officers, students and the community around the school [5]. A conducive school culture is a requirement for the implementation of an effective teaching and learning process. According to Sudrajat, school culture can be classified into three, namely academic culture, socio-cultural culture, and democratic culture [6] .

\section{Method}

This study uses a correlational quantitative approach to explain the associative relationship between the principal's leadership style and school culture and teacher performance. The population in this study were all teachers of Muhammadiyah Junior High School in Purwokerto, Banyumas Regency which consisted of Muhammadiyah 1 Purwokerto Junior High School Muhammadiyah 2 Purwokerto, and Muhammadiyah 3 Junior High School Purwokerto.In this study, the determination of the sample used a total sampling or census technique, namely a sampling technique by taking all members of the population to be used as samples, namely 67 teachers. The independent variables in this study are Principal Leadership Style (X1) and School Culture (X2) while the dependent variable is Learning Achievement (Y). The data collected in this study are in the form of score data on the principal's leadership style, school culture and teacher performance. Data collection techniques using a questionnaire. Data analysis method is by using descriptive statistical analysis method. The validation test of the analysis results is by using the normality test, linearity test, and multicollinearity test. Hypothesis test using multiple regression test. 


\section{Results and Discussion Results Normality test}

Table 1. of Normality Test Results (N Par Tests)

\begin{tabular}{llrrr}
\hline & & $\begin{array}{r}\text { principal's } \\
\text { leadership style }\end{array}$ & $\begin{array}{r}\text { School } \\
\text { Culture }\end{array}$ & \multicolumn{2}{c}{$\begin{array}{c}\text { Teacher } \\
\text { Performance }\end{array}$} \\
\hline $\mathrm{N}$ & & 74 & 74 & 74 \\
Normal Parameters & Mean & 63.6216 & 50.0405 & 51.8784 \\
& Std. Deviation & 7.02384 & 6.18978 & 5.66642 \\
& Absolute & .146 & .113 & .131 \\
Most Extreme Differences & Positive & .146 & .097 & .120 \\
& Negative & -.085 & -.113 & -.131 \\
Kolmogorov-Smirnov Z & & 1.252 & .970 & 1,130 \\
asymp. Sig. (2-tailed) & & .087 & .303 & .155 \\
\hline
\end{tabular}

a. Test distribution is Normal.

b. Calculated from data.

Based on the table above is knownthat the value of the Principal Leadership Style sig is 0.087, the School Culture sig value is 0.303 , and the Teacher Performance sig value is 0.155 . These values are more significant than 0.05 , and this indicates that the data is normally distributed, namely the distribution of data that can represent the population so that it can be continued with parametric statistical analysis.

Table 2. The Linearity Test Results of the Principal's Leadership Style variable (X1) on the Teacher Performance variable (Y)

\begin{tabular}{|c|c|c|c|c|c|c|c|}
\hline & & & $\begin{array}{l}\text { Sum of } \\
\text { Squares }\end{array}$ & df & $\begin{array}{l}\text { Mean } \\
\text { Square }\end{array}$ & $\mathrm{F}$ & Sig. \\
\hline \multirow{6}{*}{$\begin{array}{l}\text { Teacher } \\
\text { Performance * } \\
\text { Principal's } \\
\text { Leadership Style }\end{array}$} & & (Combined) & 1463,505 & 23 & 63,631 & 3,614 & .000 \\
\hline & Between & Linearity & 1033,856 & 1 & 1033,856 & 58.715 & .000 \\
\hline & Groups & Deviation from & 429,649 & 22 & 19,530 & 1.109 & .370 \\
\hline & & Linearity & & & & & \\
\hline & \multirow{2}{*}{\multicolumn{2}{|c|}{$\begin{array}{l}\text { Within Groups } \\
\text { Total }\end{array}$}} & 880,400 & 50 & 17.608 & & \\
\hline & & & 2343,905 & 73 & & & \\
\hline
\end{tabular}

Based on the table over, the comes about of the linearity test of variables Principal's Leadership Style (X1) on Teacher Performance variable (Y), it is known that the value of $\mathrm{p}$ (Sig) is 0.37 , which is more significant than 0.05.This indicates that the variable Principal's Leadership Style on Teacher Performance there is a linear relationship. Because the data is linear, thenresearch can be continued with a regression test.

Table 3. The Linearity Test Results of School Culture Variables (X2) on Teacher Performance Variables (Y)

\begin{tabular}{|c|c|c|c|c|c|c|c|}
\hline & & & $\begin{array}{l}\text { Sum of } \\
\text { Squares }\end{array}$ & df & $\begin{array}{l}\text { Mean } \\
\text { Square }\end{array}$ & $\mathrm{F}$ & Sig. \\
\hline \multirow{5}{*}{$\begin{array}{l}\text { Teacher } \\
\text { Performance * } \\
\text { School Culture }\end{array}$} & & (Combined) & 1469,855 & 20 & 73.493 & 4.456 & .000 \\
\hline & Between & Linearity & 1054,512 & 1 & 1054,512 & 63.943 & .000 \\
\hline & Groups & Deviation from & 415,343 & 19 & 21,860 & 1.326 & .208 \\
\hline & \multirow{2}{*}{\multicolumn{2}{|c|}{$\begin{array}{l}\text { Within Groups } \\
\text { Total }\end{array}$}} & 874,050 & 53 & 16,492 & & \\
\hline & & & 2343,905 & 73 & & & \\
\hline
\end{tabular}


Based on the table above, the results of the linearity test of the school culture variable (X2) on the teacher performance variable (Y) are known that the p-value (Sig) is 0.208 , which is greater than 0.05 , this indicates that the school culture variable on teacher performance there is a linear relationship. Because the data is linear, thenresearch can be continued with a regression test.

\section{Multicollinearity Test}

Table 4. Multicollinearity Test Results

\begin{tabular}{|c|c|c|c|c|c|c|}
\hline & \multirow[t]{2}{*}{ Model } & \multicolumn{2}{|c|}{$\begin{array}{c}\text { Unstandardized } \\
\text { Coefficients }\end{array}$} & $\begin{array}{c}\text { Standardized } \\
\text { Coefficients }\end{array}$ & \multicolumn{2}{|c|}{$\begin{array}{l}\text { Collinearity } \\
\text { Statistics }\end{array}$} \\
\hline & & $\mathrm{B}$ & Std. Error & Beta & Tolerance & VIF \\
\hline \multirow{3}{*}{1} & (Constant) & 15,411 & 4.397 & & & \\
\hline & $\begin{array}{l}\text { principal's leadership } \\
\text { style }\end{array}$ & .292 & .107 & .362 & .401 & 2,493 \\
\hline & School Culture & .358 & -121 & .391 & .401 & 2,493 \\
\hline
\end{tabular}

The table above shows that the tolerance value is 0.401.It can be concluded that there is no multicollinearity. Thus, it is possible to analyze the Principal's Leadership Style (X1) and School Culture (X2).

\section{Multiple Regression Analysis}

Table 5. Multiple Regression Analysis Results

\begin{tabular}{|c|c|c|c|c|c|c|}
\hline \multirow[t]{2}{*}{ Model } & & \multicolumn{2}{|c|}{$\begin{array}{l}\text { Unstandardized } \\
\text { Coefficients }\end{array}$} & \multirow{2}{*}{$\begin{array}{c}\begin{array}{c}\text { Standardized } \\
\text { Coefficients }\end{array} \\
\text { Beta }\end{array}$} & \multirow[t]{2}{*}{$\mathrm{t}$} & \multirow[t]{2}{*}{ Sig. } \\
\hline & & $\mathrm{B}$ & $\begin{array}{l}\text { Std. } \\
\text { Error }\end{array}$ & & & \\
\hline \multirow{3}{*}{1} & (Constant) & 15,411 & 4.397 & & 3.505 & .001 \\
\hline & $\begin{array}{l}\text { principal's } \\
\text { leadership style }\end{array}$ & .292 & .107 & .362 & 2,736 & .008 \\
\hline & School Culture & .358 & -121 & .391 & 2,957 & .004 \\
\hline
\end{tabular}

a. Dependent Variable: Teacher Performance

Based on result multiple regression analysis mentioned above, the regression equation can be arranged as follows:

$$
\begin{aligned}
Y_{2} & =\alpha+\beta_{1} X_{1}+\beta_{2} X_{2} \\
& =15,411+0,292 X_{1}+0,358 X_{2}
\end{aligned}
$$

The regression equation above can be explained as follows:

$\alpha=\quad$ The constant value $(\alpha)$ shows a positive value of 15.411 , which means that the value of teacher performance of 15,411 units or $0.15 \%$. Assuming there is no influence and change from other variables (other variables are fixed)

$\beta_{1}=\quad$ Variable regression coefficient value The principal's leadership style shows a positive value of 0.292 . This means that every $1 \%$ increase in the principal's leadership style in statistics causes teacher performance to increase by 0.292 or $29.2 \%$. Assuming there is no influence from other variables (other variables are fixed)

$\beta_{2}=\quad$ Variable regression coefficient value the School Culture shows a positive value of 0.358.This means that every $1 \%$ increase in school culture in statistics causes teacher performance to increase by 0.358 or $35.8 \%$. Assuming there is no influence from other variables (other variables are fixed) 
Table 6. Coefficient of Determination Test Coefficient of determination table Model Summary

\begin{tabular}{l|c|c|r|r}
\hline Model & R & R Square & Adjusted R Square & $\begin{array}{c}\text { Std. Error of the } \\
\text { Estimate }\end{array}$ \\
\hline 1 & $.709^{\mathrm{a}}$ & \multicolumn{4}{|c}{.502} & .488 & 4.05321 \\
\hline \multicolumn{3}{l|}{ a. Predictors: (Constant), School Culture, principal's leadership style }
\end{tabular}

Based on the table above, it is known that the Adjusted R square esteem is 0.488 . It shows that the ability of the principal's leadership style variable and school culture in explaining the teacher performance variable is $48.8 \%$. In comparison, the remaining $51.2 \%$ is influenced by other variables not included in the study, for example, work motivation, behavior, attitudes, and relationships.

\section{Hypothesis testing}

Table 7. t-test results table Coefficients $^{\mathbf{a}}$

\begin{tabular}{|c|c|c|c|c|c|c|}
\hline \multirow[t]{2}{*}{ Model } & & \multicolumn{2}{|c|}{ Unstandardized Coefficients } & $\begin{array}{l}\text { Standardized } \\
\text { Coefficients }\end{array}$ & \multirow[t]{2}{*}{$\mathrm{T}$} & \multirow[t]{2}{*}{ Sig. } \\
\hline & & $\mathrm{B}$ & Std. Error & Beta & & \\
\hline \multirow{3}{*}{1} & (Constant) & 15,411 & 4.397 & & 3.505 & .001 \\
\hline & $\begin{array}{l}\text { principal's leadership } \\
\text { style }\end{array}$ & .292 & .107 & .362 & 2,736 & .008 \\
\hline & School Culture & .358 & .121 & .391 & 2,957 & .004 \\
\hline
\end{tabular}

a. Dependent Variable: Teacher Performance

Based on the table of t-test results, it can be seen that the test results for the Principal Leadership Style variable $\left(\mathrm{X}_{1}\right)$ obtained a $\mathrm{t}_{\text {count }}$ value of 2,736 $>\mathrm{t}_{\text {table }} 1,996$ and a sig value of $0.008<0.05$, this means that $t_{\text {coun }} t>t_{\text {table }}$ or sig count $<\alpha$ Ha is accepted and Ho rejected which implies there's an impact of the Principal's Leadership Style on improving the Performance of Muhammadiyah Junior High School Teachers, Purwokerto, Banyumas Regency.

Based on the table of t-test results, can is known that the test results for the school culture variable $\left(\mathrm{X}_{2}\right)$ obtained a $\mathrm{t}_{\text {count }}$ value of 2,957 $>\mathrm{t}_{\text {table }} 1,996$ and a sig value of 0.004 $<0.05$.This means that $t_{\text {count }}>t_{\text {table }}$ or sig count $<\alpha$. Ha is accepted and Ho is rejected which means There is an influence of school culture on the performance of Muhammadiyah Junior High School teachers in Purwokerto, Banyumas Regency. Ho: No There is an influence of the Principal's Leadership Style and school culture on the performance of Muhammadiyah Junior High School teachers in Purwokerto, Banyumas Regency.

Ha: There are the influence of the Principal's Leadership Style and school culture on the performance of Muhammadiyah junior high school teachers in Purwokerto, Banyumas Regency.

Table 8. of F Test Analysis Results ANOVAa

\begin{tabular}{|c|c|c|c|c|c|c|}
\hline Model & & Sum of Squares & $\mathrm{df}$ & Mean Square & $\mathrm{F}$ & Sig. \\
\hline \multirow{3}{*}{1} & Regression & 1177,479 & 2 & 588,739 & 35.836 & $.000^{0}$ \\
\hline & Residual & 1166,427 & 71 & 16,429 & & \\
\hline & Total & 2343,905 & 73 & & & \\
\hline
\end{tabular}

a. Dependent Variable: Teacher Performance

b. Predictors: (Constant), School Culture, principal's leadership style 
Based on the table above, it shows that the value of $F_{0}=35.836>F_{\text {table }} 3.140$ and sig $0.000<0.005$. It shows that Ha is accepted and Ho is rejected, which meansthere is an effect of the principal's leadership style and school culture on the performance of Muhammadiyah junior high school teachers in Purwokerto, Banyumas Regency.

\section{Discussion}

The results showed a significant influence of the principal's leadership style and school culture either partially or jointly on teacher performance. In terms of partial effect, the statistical $\mathrm{t}_{0}$ value shows that the principal's leadership style variable with a $\mathrm{t}_{0}$ value $=2,736$ and $\mathrm{Sig}$. $=$ $0.008<0.05$, while the school culture variable has $\mathrm{t}_{0}=2.957$ and Sig. $=0.004<0.05$. It shows that the school culture variable has a $t_{0}$ value greater than the $t_{0}$ value for the principal's leadership style. So it can be said that the school culture variable has a more significant effect on teacher performance than the influence of the principal's leadership style on teacher performance. This is in line with Darmawan's research, that principal leadership style and school culture influenced on Tourism Cluster Vocational Schools teacher performance.

The significant influence of the principal's leadership style on teacher performance proves and strengthens the theory that the principal's leadership style can determine the intensity and quality of teacher performance in carrying out their duties [8]. Study results also show that the leadership style of the head of Muhammadiyah junior high school in the city of Purwokerto, Banyumas Regency, tends to be of the democratic type[11]. This leadership style presents a space for equality in opinion. Teachers, staff, and employees have the right to contribute to the responsibilities they carry and are part of the whole school to get a place by their dignity. Democratic leadership places the principal as someone who has the responsibility to direct, control, and evaluates [11].

The existence of a significant influence between school culture on teacher performance, proves and strengthens the theory which, states that school culture affects teacher performance and teacher commitment[9]. School culture is built from values, beliefs, assumptions, or norms that have been in effect for a long time, agreed upon, and followed by school members. School culture is not all positive, and there is negative school culture[8]. Negative school culture is a culture that is counter to improving the quality of education. For example, negative culture is coming and going home not on time, the gap between school members, lack of kinship, not respecting each other. If this negative culture continues to occur in schools, it will negatively affect the quality of education at the school [11-12]. The study results indicate that school culture has a more significant effect on teacher performance than the principal's leadership style. It can be said that school culture needs to get more attention from a leader to improve.

\section{Conclusion}

Based on the results of the analysis and discussion, it can be concluded that there is a significant influence of the principal's leadership style on the performance of Muhammadiyah junior high school teachers in Purwokerto, Banyumas Regency, this is evidenced by t-count $2.736>\mathrm{t}$-table 1.996 and sig value of $0.008<0.05$. There's a noteworthy impact of school culture on teacher performance in the performance of Muhammadiyah junior high school teachers in Purwokerto, Banyumas Regency, and this is evidenced by : t-count 2,957>t-table 1,996 and sig value of $0,004<0,05$. There is a significant influence on the principal's leadership style and school culture together with the performance of Muhammadiyah junior high school teachers in Purwokerto, Banyumas Regency, and this is evidenced byvalue $\mathrm{F}_{0}=35,836>$ F-table 3,140 and sig $0.000<0.005$. 


\section{References}

[1] Ardiana TE. Pengaruh motivasi kerja guru terhadap kinerja guru akuntansi SMK di Kota Madiun. Jurnal Akuntansi dan Pajak. 2017;17(02).

[2] Gusman HE. Hubungan gaya kepemimpinan kepala sekolah dengan kinerja guru di SMP N Kecamatan Palembayan Kabupaten Agam. Jurnal Bahana Manajemen Pendidikan. 2020 Mar 4;2(1):293-301.

[3] Baihaqi MI. Pengaruh Gaya Kepemimpinan Kepala Sekolah dan Motivasi Kerja terhadap Kinerja Guru di MA Ma'arif Selorejo Blitar. Konstruktivisme: Jurnal Pendidikan Dan Pembelajaran. 2015 Jul 15;7(2):97-106.

[4] Baihaqi MI. Pengaruh Gaya Kepemimpinan Kepala Sekolah dan Motivasi Kerja terhadap Kinerja Guru di MA Ma'arif Selorejo Blitar. Konstruktivisme: Jurnal Pendidikan Dan Pembelajaran. 2015 Jul 15;7(2):97-106.

[5] Supardi S, Hasanah E. Junior High School Students' Experiences of High Technology Based Learning in Indonesia. International Journal of Learning, Teaching and Educational Research. 2020 May;19(5):153-66.

[6] Sudrajat A. Mengapa pendidikan karakter?. Jurnal Pendidikan Karakter. 2011 Oct 4;1(1).

[7] Darmawan, Aulia. (2019). Pengaruh Gaya Kepemimpinan Kepala Sekolah dan Budaya Sekolah Terhadap Kinerja Guru (Studi Pada SMK Rumpun Pariwisata di Kota Tangerang). J. Mandiri., Vol. 3, No. 2, Desember 2019 (244 - 256). ISSN : 2580-3220, EISSN : 2580-4588Guterres, Luis Aparicio \& Supartha, Wayan Gede. (2016). Pengaruh Gaya Kepemimpinan dan Motivasi Kerja Terhadap Kinerja Guru. E-Jurnal Ekonomi dan Bisnis Universitas Udayana 5.3 (2016) : 429-454. ISSN : 2337-3067

[8] Handayani, Titik \& Rasyid, Aliyah A. (2015). Pengaruh Kepemimpinan Kepala Sekolah, Motivasi Guru, dan Budaya Organisasi Terhadap Kinerja Guru SMA Negeri Wonosobo. Jurnal Akuntabilitas Manajemen Pendidikan Volume 3, No 2, September 2015 (264-277)

[9] Setiyati, Sri. (2014). Pengaruh Kepemimpinan Kepala Sekolah, Motivasi Kerja, dan Budaya Sekolah Terhadap Kinerja Guru. Jurnal Pendidikan Teknologi dan Kejuruan, Volume 22, Nomor 2, Oktober 2014Nazir, M. (2011). Metode penelitian.Bogor: Penerbit Ghalia Indonesia

[10] Susanto, Hary. (2012). Faktor-Faktor yang Mempengaruhi Kinerja Guru Sekolah Menengah Kejuruan. Jurnal Pendidikan Vokasi, Vol 2, Nomor 2, Juni 2012

[11] Wetherell, K. M. (2002). Principal leadership style and teacher job satisfaction. Seton Hall University Dissertations and Theses (ETDs). 1400.

[12] Al-Safran, E., Brown, D., \& Wiseman, A. (2014). The Effect of Principal's Leadership Style on School Environment and Outcome. Research in Higher Education Journal, 22. 